\title{
Is CFIUS insurmountable for Chinese enterprises? --- from the Perspective of HNA Group - Ingram Micro Case
}

\author{
Chanting Chen ${ }^{1, \mathrm{a}, *}$ \\ ${ }^{1}$ East China University of Political Science and Law, No. 555 Longyuan Road, Songjiang District, Shanghai, \\ China \\ a chenchanting@126.com \\ *Corresponding author
}

Keywords: CFIUS, National Security Review, Foreign Investment

\begin{abstract}
The increase of CFIUS review and investigation numbers, the frequency of veto decisions, the newly enacted FIRRMA, eta, all these signal to Chinese investors that CFIUS is raising scrutiny of foreign investment. Yet it is not appropriate to think that CFIUS is born to be hostile to Chinese investors and therefore insuperable. The HNA Group-Ingram Micro case is a good example to show that if two transaction parties work together, taking full advantages of the informal review process, it is possible for them to get CFIUS approval when the time is right. Treating CFIUS review in a calm and mature way will make the process more successful.
\end{abstract}

\section{Introduction}

Recently years have witnessed a rapid increase in CFIUS reviews and investigations to foreign investment, especially investment from China or related with China. The tightening scrutiny has chilled enthusiasm of Chinese investors for the U.S. market. The newly enacted Foreign Investment Risk Review Modernization Act of 2017 (FIRRMA) extends the CFIUS process and enlarges CFIUS jurisdiction. Many are concerning that CFIUS is a "natural enemy" for Chinese investment. The negative impression would bring resentment instead of solutions. Study of the successful HNA Group's acquisition of Ingram Micro case could be a good example for Chinese investors to learn from.

\section{The Increasing Number of CFIUS Reviews}

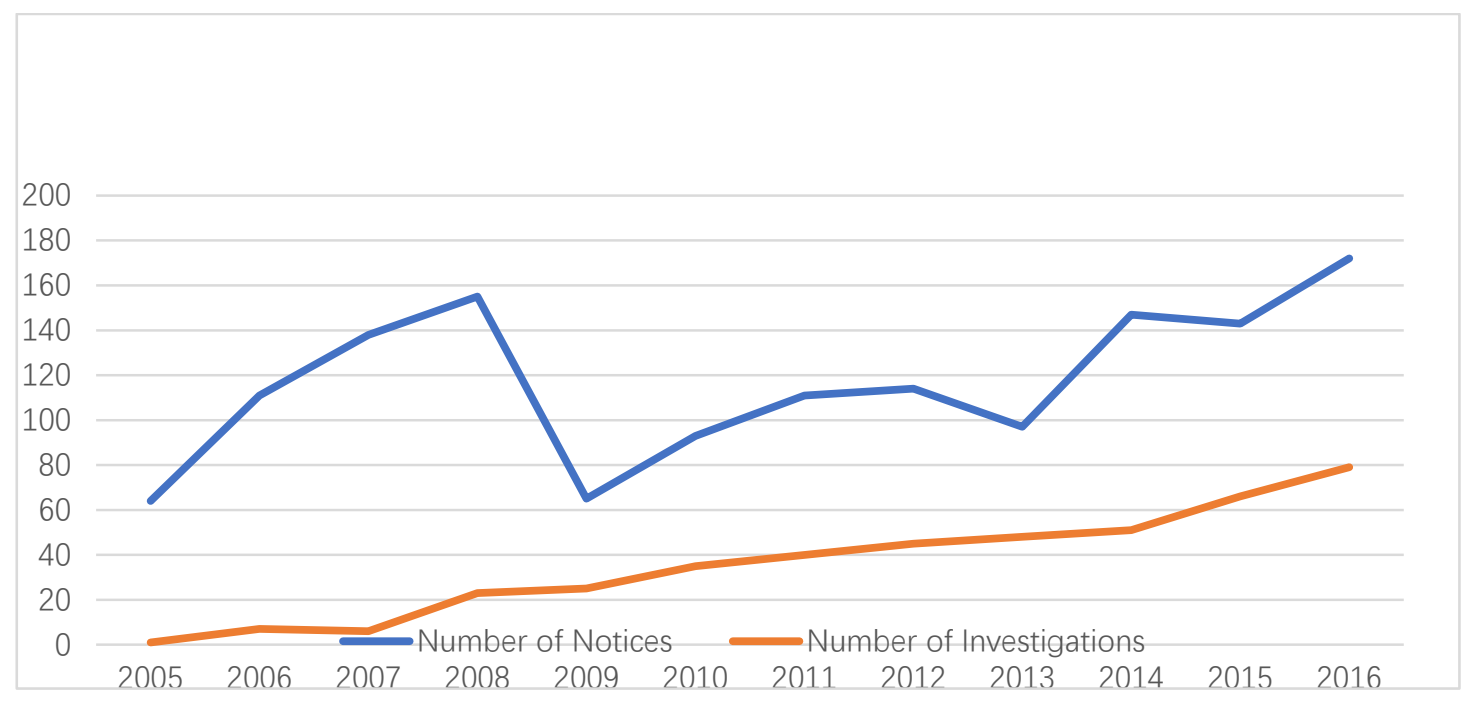

Figure 1 Number of Notices and Investigations (2005-2016)

Source: data collected from US Treasury website.

According to data provided by the U.S. Treasury Department, there is a rapid increase of the 
number of cases reviewed since the sharp drop in notification number in the year 2008 due to the financial crisis. [See Figure 1] The Number of notification submitted reached a historic new high point to 172 in 2016. Different from the fluctuation of the number of the case filed to CFIUS, the number of the cases investigated by the Committee has been maintaining a consistent growth. Increase in investigation proportion is a good explanation to say that CFIUS has becoming more cautious since the Dubai Port World case.

\section{Unprecedented Pressures Faced by Chinese Enterprises}

For Chinese corporations, the CFIUS process has been one of the major obstacles for entering US market. The frequent frustration has greatly reduced the enthusiasm of Chinese enterprises to invest in the US market. According to Rhodium Group statistics, the total number of direct investment from China was only $\$ 1.8$ billion in the first half of 2018, dropping more than 90\% from the same period in the year of 2017, reaching the lowest point in seven years. [ See Figure 2] [1]

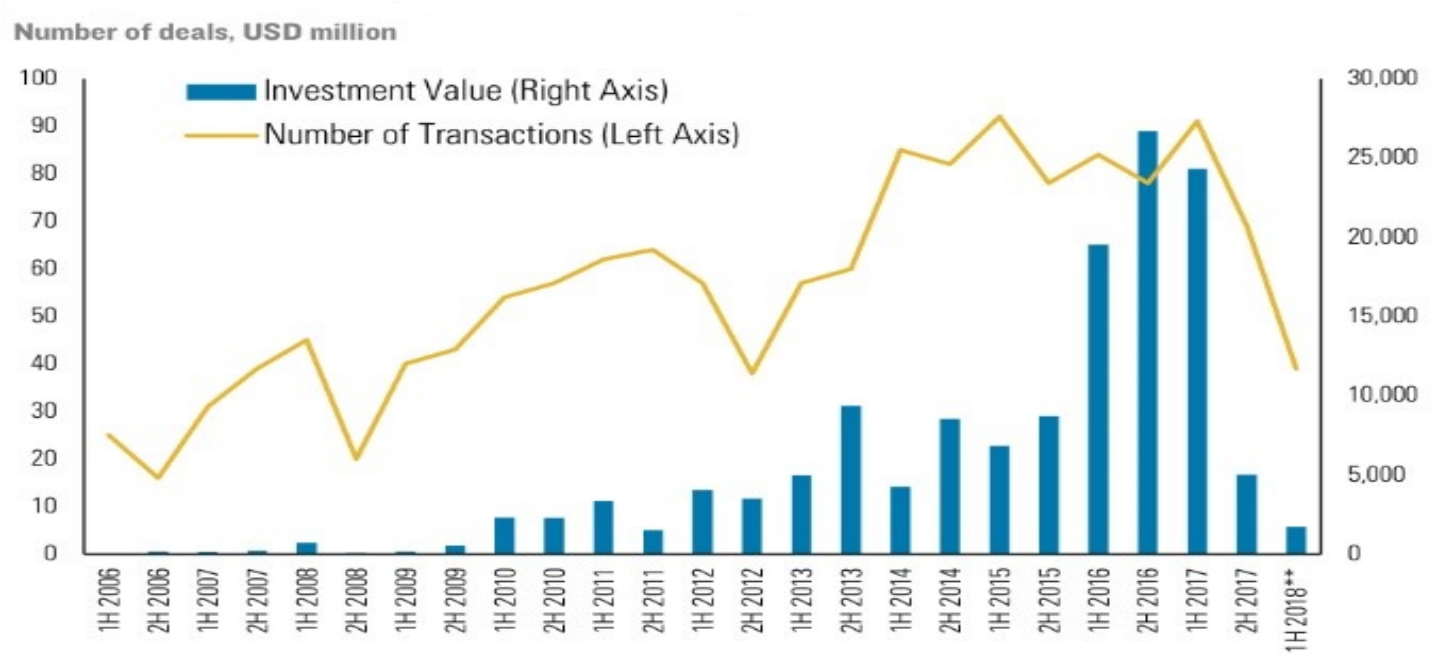

Figure 2 Completed Chinese FDI Transactions in the US* (2006-2018)

Source: Rhodium Group. *Includes completed M\&A transactions with over $10 \%$ resulting stake and greenfield projects that have broken group; **January to May 2018.

Another negative news for Chinese companies about the CFIUS process is that since the establishment of national security review system, there are five cases officially rejected by the President. These are the China National Aero-Technology Import and Export Corporation's acquisition of MAMCO, a U.S. manufacturer of aircraft components, Ralls Corporation's acquisition of four Butter Creek windfarm projects, Chinese Fujian Grand Chip Investment Fund's acquisition of Aixtron, a Germany-based semiconductor firm, Canyon Bridge's acquisition of Lattice Semiconductor, and Broadcom's acquisition of Qualcomm.[2] Among them 4 are related to China. In the latest Broadcom's acquisition of Qualcomm case, although there is no Chinese investment involved, there is a concern that the deal would weaken the U.S. leadership in mobile telecommunication industry, so as to let Huawei take the leading place.[3] Besides, except the China National Aero-Technology Import and Export Corporation - MAMCO case, which is the only one case in early year of CFIUS review, all the other four cases happened after the financial crisis. This trend reflects that the US has been strengthened its national security review in the post financial crisis era, when Chinese enterprises accelerate their pace of going abroad.

\section{The HNA Group - Ingram Micro Case}

Tianjin Tianhai Investment Development Co., Ltd., a subsidiary Of China’s HNA Group, purchased Ingram Micro at the end of 2016. Ingram Micro, with the revenues of $\$ 47$ billion in the 
fiscal year 2017, is one of the largest providers of internet technology products and services in global market, and ranked $170^{\text {th }}$ in Fortune 500.[4] The price for the purchase was around USD 6.09 billion in the all cash payment. Tianhai invested RMB 8.7 billion with its own capitals, the Guohua Life Insurance Co., Ltd. invested RMB 4 billion, and the rest of the investment were from bank mergers and acquisitions loans.[5]

As the world's leading technology and supply chain service provider, Ingram Micro has established a close business tie with many global champions, including Amazon, Microsoft and Dell. The company has a large list of customers, and masters advanced technology in virtual storage, network equipment and data acquisition. Also, company businesses such as the on-site data destruction and the data storage services enable the company to access various industry information. The case caught CFIUS attention for it matches national security consideration factors, such as the loss of command of key technology to the Chinese company, the effect on U.S. leadership in big data, and the reveal of key customers' information. The positive result of national security review makes the transaction a good studying case for later Chinese acquirers.

\subsection{Enlightenment One: Parties' Cooperation Helps Success}

For host countries, the foreign investment national security system is the shielding for their safety and best interests in the foreign investment domain. For business enterprises, the system could be used as an institutional tool preventing competitors from entering the US market. Take the case of CNOOC's aborted acquisition of Unocal for example. CNOOC and Chevron were well-matched bidders. Chevron lobbied CFIUS and Congress to reject CNOOC's bid with the argument that part of CNOOC's acquisition cash was funded with the low-interest loans from state-controlled banks. This argument augmented national security concerns over the case. CNOOC finally withdrew its bid due to the unpredictable political pressure.[6]

Different from CNOOC - Unocal case, HNA Group's acquisition of Ingram Micro was a win-win business. For Ingram Micro, its income in the Asia-Pacific region accounts for more than $20 \%$ of the total revenue before the acquisition. The Asia-Pacific region has becoming an increasingly important source of profits. China provided $5.4 \%$ revenue for the corporation in the year of 2015, which accounted for $23.1 \%$ of the enterprise profits. The acquisition would help to bring Chinese customers and expand the US company's business in Chinese market.[7] For the Chinese counterpart, it would make Tianhai one of the largest IT distribution company in the world and HNA Group was expected to become the world top 100 enterprises with the acquisition of Ingram Micro.

The complementary advantages between HNA Group and Ingram Micro encourages these two companies to work together for the CFIUS review. Also, HNA Group is lucky for there is no strong competitors coveting the same target. These two points ensure the final success of the business.

\subsection{Enlightenment Two: The Informal Review Process is Important}

The CFIUS review traditionally lasts 90 days, including 30-day initial review, 45-day investigation, and 15-day presidential decision. FIRRMA for the first time extends the review time limitation to 120 days, consisting of 45-day initial review, 60-day investigation, and 15-day presidential decision.[8] The statutory review time is not long enough either for parties to convince CFIUS, or for CFIUS to fully understand the case. Therefore, ever since the establishment of foreign investment national security system, there has been an informal review process before parties formally file the application notice.

There is no time limitation for the informal review. It is important for both CFIUS and transaction parties. For CFIUS, this stage provides sufficient time to investigate the case thoroughly and make an assessment accurately. For transaction parties, the informal review provides opportunities to have an in-depth communication with CFIUS members and avoid negative public feedback by stopping trading before the business is formally called off due to security reasons. HNA Group and Ingram Micro take fully advantage of the informal stage to convince and work with CFIUS, which ensures CFIUS’ approval of the transaction. 


\subsection{Enlightenment Three: A good Timing Indicates a Good Result}

The result of CFIUS review is closely related to government policies. Firstly, from the perspective of the committee's personnel composition, it is an inter-agency committee consisting of nine heads of government departments and offices. Secondly, the definition of national security is left open to give the President and the committee discretion to redefine it. Thirdly, the Presidential decision in national security review is not subject to judicial review and is not actionable. These system arrangements contribute to the politicization of the CFIUS review.

When the government is more open to the foreign investment, foreign corporations are comparatively easier to have an affirmative feedback from CFIUS. If the government consider national security as an incomparable priority, it would indicate a stricter CFIUS review. It has been observed that the acquisition between HNA Group and Ingram Micro is wisely winded up in December 2016, timely avoiding the unpredictability that might brought by the government transition.

\section{The Rationale of CFIUS Review}

The positive and negative dual characters of the international investment require an effective measure to ensure the best interests and absolute security of sovereign states. CFIUS review from the very beginning has clarified its function as "to ensure national security while promoting foreign investment and the creation and maintenance of jobs."[9] Though the practical effect of CFIUS review in FIRRMA era is still unknown, it is officially stated that FIRRMA will continue the mission of CFIUS review.[10] The foundation of the review system guarantees CFIUS to implement national security review rationally and prudentially so as to maintain the balance between economic interests and national security impacts brought by inbound investments.

In addition, the foreign investment national security review is not a routine regulation. Even American people have only limit understanding of CFIUS and its operation process due to the nonpublication of the review procedure. Still the review is not as mysterious as what the outside world describes. US corporations usually work together with specialized lawyers to handle the review process. So should their Chinese counterparts do. CFIUS review is a reasonable national security safeguard mechanism, not an insurmountable obstacle. Once removing the fear and aversion, it would be psychologically easier for Chinese companies to have the national security review.

\section{Conclusion}

On August 13, 2018, the US President signed FIRRMA. The Act is officially claimed to be country-neutral and continuing the mission of CFIUS review as to secure national safety while welcoming foreign investment.[11] Still, many are concerning that it will be more difficult for Chinese enterprises to invest in the United States in the future due to the extension of CFIUS jurisdiction, the longer official review time and the US-China trade friction background. The practical effect of FIRRMA to CFIUS process remains to be seen, and the HNA Group - Ingram Micro case can be a guidance for future investors.

\section{Acknowledgements}

This research was financially supported by the East China University of Political Science and Law Research Projects.

\section{References}

[1] Thilo Hanemann, Arrested Development: Chinese FDI in the US in $1 \mathrm{H} \mathrm{2018,} \mathrm{available} \mathrm{at}$ https://www.rhg.com/research/arrested-development-chinese-fdi-in-the-us-in-1h-2018/, last visited on Oct. 5, 2018. 
[2] James K. Jackson, The Committee on Foreign Investment in the United States (CFIUS), July 3, 2018, available at https://fas.org/sgp/crs/natsec/RL33388.pdf, last visited on Sept. 2, 2018.

[3] Qualcomm Inc/DE FORM 8-K, available at https://kpbs.media.clients.ellingtoncms.com/news/documents/2018/03/06/Form-8-K-Current Report- 3.6.18_Letter.pdf., last visited on Sept. 23, 2018.

[4] About Ingram Micro, available at http://www.ingrammicro.com.cn/cmsB4login/LoginContext.cfm?context_id=45, last visited on Aug. 25, 2018.

[5] Snake Swallows Elephant, HNA Acquires Giant IT Distributor Ingram Micro, available at http://money.163.com/16/1205/20/C7I52FJ6002580S6.html, last visited on Aug. 25, 2018.

[6] CNOOC Said Withdrawing Unocal Bid Not for Economic Reason, available at http://news.xinhuanet.com/fortune/2005-08/03/content_3305986.htm, last visited on Oct. 9, 2007.

[7] Shanshan Chen, Six Billion Dollars to Buy Ingram Micro, HNA Group become World's Top 100 Enterprises, available at http://news.163.com/air/16/1205/08/C7GS4KO3000181O6.html, last visited on Aug. 30, 2018.

[8] TITLE XVII - REVIEW OF FOREIGN INVESTMENT AND EXPORT CONTROLS, SEC. 1709. TIMING FOR REVIEWS AND INVESTIGATIONS, available at https://home.treasury.gov/sites/default/files/2018-08/The-Foreign-Investment-Risk-Review Modernization-Act-of-2018-FIRRMA_0.pdf, last visited on Sept. 2, 2018.

[9] FOREIGN INVESTMENT AND NATIONAL SECURITY ACT OF 2007, available at https://www.congress.gov/110/plaws/publ49/PLAW-110publ49.pdf, last visited on Oct. 5, 2018.

[10] [11] FIRRMA FAQs, available at https://www.treasury.gov/resource-center/international/Documents/FIRRMA-FAQs.pdf., last visited on Sept. 20, 2018. 